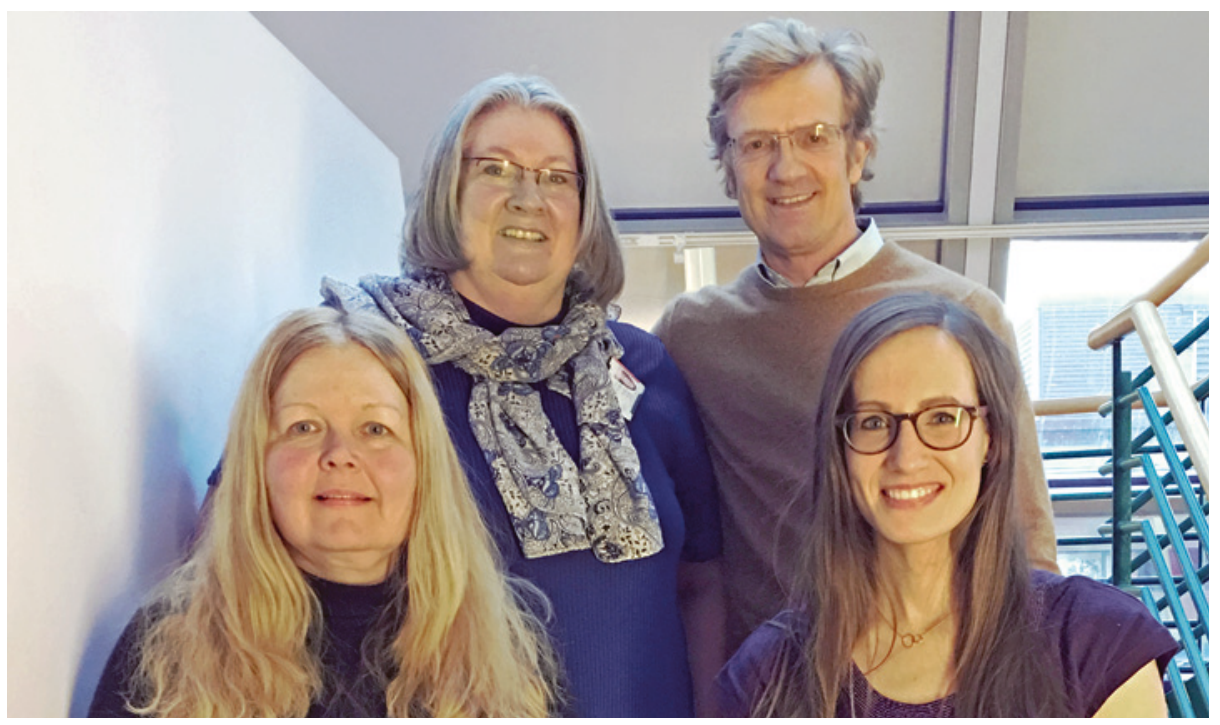

Fra venstre: Liv Mundal, Kirsten B. Holven, Kjetil Retterstøl og Henriette Walaas Krogh. Foto: Ane Sørlie Kværner

\title{
Kardiovaskulær sykdom ved familiær hyperkolesterolemi
}

Flere enn ni av ti pasienter med arvelig høyt kolesterol har kardiovaskulær sykdom ved sin død, viser ny norsk studie.

Familiær hyperkolesterolemi er en genetisk tilstand som medfører økt kolesterolnivå i blodet. Ubehandlet familiær hyperkolesterolemi øker risikoen for tidlig aterosklerose og dermed risikoen for kardiovaskulær sykdom i ung alder. I en studie publisert i European Heart Journal har forskere ved Oslo universitetssykehus og Universitetet i Oslo undersøkt forekomsten av kardiovaskulær sykdom hos døde pasienter med familiær hyperkolesterolemi (1).

Studien er basert på data fra journaler til 79 pasienter med familiær hyperkolesterolemi og som døde i perioden 1989-2010. Kardiovaskulær sykdom var dødsårsaken hos rundt halvparten av pasientene, som i gjennomsnitt var 60 år da de døde, likt hos begge kjønn. Gjennomsnittsalderen ved tidspunkt for diagnosen var 44 år hos begge kjønn. Alle mennene og $84 \%$ av kvinnene hadde kardiovaskulær sykdom på dødstidspunktet. Koronarsykdom, definert som hjerteinfarkt eller angina, var til stede hos $86 \%$ av pasientene, og $69 \%$ hadde hatt ett eller flere hjerteinfarkt.

De som døde før fylte 60 år hadde høyere nivå av LDL-kolesterol ved siste måling før de døde, til tross for at flere av dem sto på statiner, og andelen røykere var høyere.

- Denne studien viser at pasientene med familiær hyperkolesterolemi døde altfor tidlig og at nesten alle hadde etablert kardiovaskulær sykdom ved dødstidspunktet. Mange personer med familiær hyperkolesterolemi får ikke stilt diagnosen før de har hatt hjerteinfarkt eller annen kardiovaskulær sykdom, sier artikkelens andreforfatter Liv Mundal, som er kardiolog og stipendiat ved Lipidklinikken ved Oslo universitetssykehus og Universitetet i Oslo. - Vårt mål med studien var å vise hvor viktig det er at personer med arvelig høyt kolesterol får behandling med kolesterolsenkende medisiner så tidlig som mulig, supplerer førsteforfatter og klinisk ernæringsfysiolog Henriette Walaas Krogh.

\section{Forskningsmiljø rundt familiær hyperkolesterolemi}

Denne studien inngår i ph.d.-prosjektene til Henriette Walaas Krogh og Liv Mundal, som begge er tilknyttet Oslo universitetssykehus og Universitetet i Oslo. Forskningsprosjektet springer ut fra forskningsmiljøer på Avdeling for ernæringsvitenskap, Universitetet i Oslo, der både Kjetil Retterstøl og Kirsten B. Holven har hovedstilling, og Lipidklinikken ved Oslo universitetssykehus, der Kjetil Retterstøl har bistilling som overlege og forsker, samt Nasjonal kompetansetjeneste for familiær hyperkolesterolemi, der Kirsten B. Holven har bistilling som forskningsansvarlig.

\section{Kaveh Rashidi}

Tidsskriftet

\section{Litteratur}

1. Krogh HW, Mundal L, Holven KB et al. Patients with familial hypercholesterolaemia are characterized by presence of cardiovascular disease at the time of death. Eur Heart J 2015; ehv602.
Ordforklaringer:

Familiær hyperkolesterolemi: Arvelig høyt kolesterol som skyldes mutasjoner i LDLreseptorgenet. 